\title{
Thoughts on Reform and Establishment of Practice- Oriented Undergraduate Start-Up Curricula
}

\author{
Hong Zhao ${ }^{1, *}$ \\ ${ }^{1}$ Liaoning Institute of Science and Technology, High and New Technology Industrial Development Zone, Benxi, \\ Liaoning, 117004, China \\ EMAIL.Hongz0908@163.con
}

\begin{abstract}
It is one of the key tasks in the future education to transform the regional colleges and universities from ordinary undergraduate institutes to practice-oriented ones. Entrepreneurship training is the core to achieve the transformation of these higher education institutes. In the process of transformation around the essential entrepreneurship education system, the reform and establishment of entrepreneurship curriculum is particularly important. This paper starts with the current situation of start-up curricula for undergraduates in practice-oriented colleges and universities, and figures out problems in the training, such as inadequate understanding, inconsistent content, lack of teachers, out-of-date methods, superficial practices and incomplete systems. Based on these problems, the paper puts forward some ideas for the launch of entrepreneurship curriculum reform for undergraduates in practice-oriented colleges and universities. Keywords: practical undergraduate curricula, reform of start-up curricula, establishment, thoughts
\end{abstract}

\section{INTRODUCTION}

Since 1980s, there has gradually formed a new trend in the international higher education, that is, the prevalent focus of practical teaching \& learning and the emphasis of talent development with practical skills. Many colleges and universities in China have also tended to emphasize the enhancement of the practical atmosphere when exploring the reform approaches of education, since the public has raised their awareness that practical teaching \& learning is a key step in the cultivation of students' practical and innovative abilities, as well as an essential way to improve their soft skills and competitiveness for further career in the society ${ }^{[1]}$.

'Practice-Oriented Undergraduate Curricula' belongs to a revolutionary attempt of a combined educational mode of the innovative undergraduate education and the new College education. Practical undergraduate talents are supposed to be developed in some provincial colleges for undergraduates and universities, national exemplary training institutes and national significant enterprises as joint pilots to meet the needs of social and economic development ${ }^{[2]}$. The practice-oriented undergraduate education refers to the undergraduate colleges with the practice orientation rather than the scientific research. In the current stage, it generally includes all the second tier and the third tier of universities in the college entrance examinations. The practice-oriented undergraduate education has played a positive role in meeting the needs of Chinese economic and social development as well as the requirement of talents with high-leveled application skills, promoting the prevalence of higher education in China.
As the economy develops and the employment problems become severe, it is essential in the innovation of higher educational institutes to cultivate start-up undergraduates with practical skills. The general abilities of undergraduates will improve and the employment tension may be reduced by improving the innovation spirit and basic abilities \& skills of self employment through start-up training.

\subsection{Current development Situations and Problems of Practical Undergraduate Curricula on Entrepreneurship}

\subsubsection{Inadequate Understanding, without Consistent Entrepreneurship Education Ideologies}

Currently, the managers of practice-oriented institutes in China fail to pay enough attention to entrepreneurship education for college students, and there is no relevant curriculum for entrepreneurship education in education plans and development plans. Many campuses only carry it out as a way of employment guidance and ideological lectures, rather than include it in the official teaching system. As a result, lecturers' understanding of the significance of practical entrepreneur training and start-up education remains superficial, which aggravates students' neglect of innovation and entrepreneurship. Despite some previous understanding towards the concept, it is common to witness cases with waiting, hesitation, carelessness and 
utilitarianism, restrained by conditions, the environment and foundations ${ }^{[3]}$.

\subsubsection{Inconsistent Contents, with Teaching Plans Requiring Further Adjustment}

China's entrepreneurship education is still in the initial stage of development, and higher educational institutes have not established a comprehensive and systematic curriculum system for all students. It is not strange to see that the curriculum of entrepreneurship education is incomplete with limited views and categories, lack of systematization, and the proportions of theoretical and practical academic hours are not coordinated. Meanwhile, the course orientation of entrepreneurship education is still vague and lacks professional teaching reference guidance, which causes obstacles to the development of the course. The curriculum of entrepreneurship education is only available to a small number of students, which also hinders the development of general entrepreneurship education.

\subsubsection{Lack of Teachers, Short of Teaching Resources for Practical Education}

Instructors are significant to the success of entrepreneurship education. For now, there is a lack of teachers who have not only theoretical knowledge of entrepreneurship education, but also some practical experience in enterprises. Some colleges and universities have no full-time lecturers of entrepreneurship courses, and therefore the administrative staff or tutoring personnel of the employment guidance department are hired to lecture. Most of these non-professionals are lack of knowledge base of entrepreneurship education. Even though their knowledge is relatively extensive, most of them are not familiar with enterprise operation. In the teaching process, they are more inclined to preach according to the book and theory, and the classroom teaching content is unable to meet the curriculum requirements. In this case, it is also more difficult to be competent for the relevant practical guidance tasks.

\subsubsection{Out-Of-Date Methods, Short of Modern Teaching Methods and Modes}

The teaching mode and means of entrepreneurship education in undergraduate colleges are relatively simplifies in the current context, which cannot meet the needs of curriculum, and causes low student recognition. This is reflected in the following aspects: (1) Most of them adopt the method of "theory teaching", which means they attach great importance to theoretical education instead of practical teaching. It neglects the cultivation of students' entrepreneurial practice ability, and limits the enthusiasm of teachers' education reform; (2) The traditional way of "lecture and listen" is delivered in the classroom, which cannot stimulate students' participation in the classroom and trigger their interest in entrepreneurship.

\subsubsection{Ineffective Practices, with Under- Developed Practice Base Construction Inside and Outside Campus}

Undergraduate institutes pay less attention to the launch of the entrepreneurship practice system, and there are problems such as lack of diversity and frequency of entrepreneurial practice simulation courses and selfemployment practice activities. In the current stage, it is common for the internship practices to be superficial off campus. On the one hand, it is due to the tendency of managers to pursue the maximum of short-term interests after the reform of enterprises in China. On the other hand, it is because of the limited investment of funds and human resources in this field. Moreover, due to the lack of indepth cooperation between the government, schools and enterprises, there are still many flaws in their cooperation, which cannot achieve great performance in entrepreneurship education practices.

\subsubsection{Incomplete Systems, Lack of Roles in Education Evaluation Mechanism}

The current teaching evaluation mechanism fails to meet the needs of practical teaching reform, and cannot play a positive role in encouraging practical teaching and innovation in the teaching process ${ }^{[4]}$. On the contrary, it has restrained the practice. In particular, the evaluation results of students' practical course and the conversion of teachers' practical teaching workload require further explorations.

\subsection{Thoughts on Reform and Establishment of Practice-Oriented Undergraduate Start-Up Curricula}

\subsubsection{Start-Up Education Serves Innovative Construction of the Nation}

People are the most critical factor in innovation, and innovation motivations equal talent motivations. Keqiang $\mathrm{Li}$ indicated in the innovation and entrepreneurship competition of college students that college students are the newly-born force to implement the innovation-driven development strategy and promote mass entrepreneurship and popularize innovation. They should not only work on acquiring and grasping more knowledge, but also devote themselves to innovation \& entrepreneurship and improve their practical ability. We should integrate innovation \& entrepreneurship education into talent development, effectively enhance students' entrepreneurship awareness, 
innovation spirit and creativity. It is like cultivating a solid foundation for mass entrepreneurship and innovation, so as to provide continuous intellectual supports for establishing an innovative nation. We should further enhance the reform and higher education development. We should establish a scientific educational concept, implement the basic task of cultivating talents with virtues. We should optimize the academic structure, improve the quality of education, boost the all-round development of students in innovation and entrepreneurship, and adapt to and serve the economic \& the social development as well as national strategic needs.

\subsubsection{Building the "Three in One" Entrepreneurship Education Model of Universities, Governments and Enterprises}

The report of the 17th National Congress of the Communist Party of China pointed out that "we should implement the development strategy of expanding employment and boost entrepreneurship to eventually impact employment." In the face of the problems existing in the entrepreneurship education of college students, we should create a "three in one" model of entrepreneurship education for college students with the initial attempt of colleges and universities, the strong support of the government and the full cooperation of enterprises. The government, colleges and enterprises should cooperate closely to carry out entrepreneurship education for college students, which is an important step to implement the national strategy of entrepreneurship employment, expand employment and build an innovative nation. It is also essential for the new model of curriculum reform targeting college students ${ }^{[5]}$.

\subsubsection{Holding Start-Up Education Ideology of "People-Orientation"}

"People-orientation" is the essence of the modern education value. In the context of start-up training in higher education institutes it means "student-orientation". In other words, it aims to develop innovative talents and concentrate on the inspirations and guidance for students, highlighting independent thinking, self-refection and personal development. It insists on the principles of comprehensiveness, inspirations, practices, equality and interactions, training start-up talents who have the courage, the gifts and the determinations with innovative skills from the perspectives of growth and development.

\subsection{Solutions for Reform of Practice-Oriented Undergraduate Start-Up Curricula}

\author{
1.3.1 Transforming Teaching Ideology of \\ Entrepreneurship and Raising Awareness of \\ Correct Start-Up Ideas
}

Carrying out extensive and in-depth publicity and learning can help students and their parents change the traditional concepts of employment in time, guide students to establish a new concept with entrepreneurship education as the core, and build a positive campus culture of entrepreneurship; meanwhile, it can improve teachers' ideological understandings of innovation and entrepreneurship, establish a correct awareness of entrepreneurship education, and form a consistent system of thoughts, concepts and actions.

\subsubsection{Adjusting Start-Up Curricula and Improving Entrepreneurship Course Systems}

Practice-oriented institutes for undergraduates should include entrepreneurship education in the subject catalogue, establish independent teaching departments or relevant education research centers to be responsible for entrepreneurship education, and build a curriculum system of entrepreneurship education with its own characteristics. The curriculum system of entrepreneurship education should be based on the actual situation of college students, scientifically design the syllabus, emancipate the mind, boldly adjust the teaching plan, and strive to maximize the proportion of practical teaching hours and curriculum structure. On the other hand, we should divide the entrepreneurship education into different levels and specialties, and set up curriculum contents according to different majors or different grades, so that the entrepreneurship curriculum and the specialty curriculum are both divided and cooperated, as well as mutually independent and connected ${ }^{[6]}$. Secondly, we should pay attention to the increase of GYB, SIYB and other entrepreneurial simulation training events for college students. 
Table 1: Applied Undergraduate Entrepreneurship Education Curriculum System

\begin{tabular}{|c|c|c|c|c|}
\hline $\begin{array}{l}\text { Entrepreneurship } \\
\text { Education } \\
\text { Content }\end{array}$ & $\begin{array}{c}\text { Course } \\
\text { Categories }\end{array}$ & Major Courses & Elective Courses & Objective \\
\hline $\begin{array}{l}\text { Entrepreneurship } \\
\text { Education } \\
\text { Theory }\end{array}$ & $\begin{array}{l}\text { Basic } \\
\text { Theoretical } \\
\text { Course }\end{array}$ & $\begin{array}{c}\text { Foundation of } \\
\text { Entrepreneurship, } \\
\text { Marketing, } \\
\text { Innovation Design, } \\
\text { Enterprise Operation and } \\
\text { Management, } \\
\text { Financial Planning, } \\
\text { Public Relations, } \\
\text { Enterprise Risk } \\
\text { Management, } \\
\text { Economic Law, } \\
\text { Entrepreneurship }\end{array}$ & $\begin{array}{l}\text { Enterprise Accounting, } \\
\text { Intellectual Property, } \\
\text { Management } \\
\text { Psychology, } \\
\text { Market Investigation } \\
\text { and Prediction, } \\
\text { Business Etiquette, } \\
\text { Business Negotiation } \\
\text { Skills, } \\
\text { Speech and Eloquence, } \\
\text { Business Operation, } \\
\text { Strategic Management. }\end{array}$ & $\begin{array}{l}\text { Help students get } \\
\text { essential abilities of } \\
\text { start-up business, } \\
\text { and learn basic theories } \\
\text { and approaches. }\end{array}$ \\
\hline $\begin{array}{l}\text { Innovation and } \\
\text { Entreneurship }\end{array}$ & $\begin{array}{l}\text { Entrepreneurship } \\
\text { Practice Couse }\end{array}$ & $\begin{array}{c}\text { Business Plan } \\
\text { Preparation, } \\
\text { Entrepreneurship GYB } \\
\text { Simulation Training, } \\
\text { Entrepreneurshio SIYB } \\
\text { Simulation Training, } \\
\text { School-enterprise Joint } \\
\text { Practice. }\end{array}$ & $\begin{array}{c}\text { Entrepreneurial Practice, } \\
\text { Entrepreneurship } \\
\text { Lectures, internship } \\
\text { program }\end{array}$ & $\begin{array}{l}\text { Let students know more } \\
\text { about how to start-up } \\
\text { business in working } \\
\text { process, } \\
\text { operational processes, } \\
\text { and gain experiences. } \\
\text { They can improve } \\
\text { innovation and } \\
\text { entrepreneurial abilities. }\end{array}$ \\
\hline $\begin{array}{l}\text { Quality of } \\
\text { entrepreneurship }\end{array}$ & $\begin{array}{l}\text { Competency } \\
\text { Development } \\
\text { Course }\end{array}$ & $\begin{array}{c}\text { Entrepreneur share } \\
\text { experience, } \\
\text { Entrepreneurial } \\
\text { Experience, } \\
\text { Entrepreneur Interview }\end{array}$ & $\begin{array}{l}\text { Team-work Training, } \\
\text { Survival Training. }\end{array}$ & $\begin{array}{l}\text { According to successful } \\
\text { entrepreneurs' } \\
\text { experience, } \\
\text { students can improve } \\
\text { their essential abilities, } \\
\text { which would be } \\
\text { necessary in the process } \\
\text { of starting a business. }\end{array}$ \\
\hline
\end{tabular}

\subsubsection{Optimizing Teaching Teams and Enhancing Teacher Team-Building}

As the leader of talent development, teachers of practiceoriented universities are also practitioners of talent education. (1) We should advance the research by the teachers on the theory of entrepreneurship education, promote the research tasks for entrepreneurship and entrepreneurship education, improve the research funds; (2) We should introduce the outstanding experts with higher professional titles and rich practical experience to expand the teaching team; (3) We should guide and organize the teachers to contact with relevant enterprises and organizations, cultivate both theory and practice in order to improve the quality of entrepreneurship education instructors.

\subsubsection{Advancing Reform of Teaching Modes and Focusing on Diversifying Teaching Methods}

(1) To organize entrepreneurship competitions: we should emphasize the cultivation of entrepreneurship abilities of college students by simulating entrepreneurship contexts, volunteering to guide them to participate in specific entrepreneurship projects, encouraging them to apply for "Challenge Cups" and other entrepreneurship design competitions. As a result, students can combine entrepreneurship concepts with theoretical knowledge acquired in class, cultivate entrepreneurship abilities of each individual and each group, and enrich relevant knowledge and experience; (2) To combine entrepreneurship education and professional teaching: only when start-up education and professional courses of various disciplines are integrated, can students' integration capabilities of theory and practice be improved, and their professional knowledge can be applied flexibly; (3) to conduct practical teaching: by providing more entrepreneurial practice opportunities for students through entrepreneurship education bases, "entrepreneurship incubators", entrepreneurship experiment center, etc., we can enrich students' experience of innovation and entrepreneurship, and promote students from "Wanting to start a business" to "being able to start a business", and finally realize the transformation of "creating a successful business"; (4) to teach with entrepreneur cases: institutes 
standards and methods, and formulate a practical evaluation, supervision and guidance system referring to the overall orientation of the training objectives of entrepreneurship education ${ }^{[7]}$.

\section{CONCLUSION}

\subsubsection{Enhancing Cooperation between Campuses and Enterprises to Build Platforms for Social Practices}

First of all, schools should provide venues, establish entrepreneurial bases and practical platforms for regular entrepreneurial training, encourage individual students and groups to participate in entrepreneurial activities, so that the entrepreneurial base can truly become the initiation and the "cradle" for trainers to engage with the society. Secondly, in the process of implementing entrepreneurship education, colleges and universities should continue practicing with social enterprises in many ways and channels, so as to provide time for students to practice and cultivate their entrepreneurial ability. For example, colleges and universities sign economic contracts with enterprises, and students take in charge of the operation, eventually helping them perfect their entrepreneurial skills.

\subsubsection{Referring to Experiences Overseas to Learn}

The systems of undergraduate start-up policies, services, education and self-employment atmosphere in those developed counties are great references for China. Many countries have applied the combined innovative mode of "politics, production, learning", such as the comprehensive mode in America, Germany's apprenticeship mode, Britain's implantation mode and Japan's union mode. The new solution for the innovation of entrepreneurship curricula is to positively introduce advanced educational ideas overseas as well as their curriculum systems and teaching modes, adopt diversified teaching methods, and explore the practice-oriented entrepreneurial talent training mode to meet the requirements of the development of the modern context.

\subsubsection{Setting up Completed Systems and Improving Teaching Outcomes of Start-Up Training}

A well-rounded practical teaching management system is a powerful guarantee for the normal operation of the practical teaching system. In the evaluation of entrepreneurship education in practice-oriented undergraduate institutes, we should attach importance to the teaching evaluation with entrepreneurship courses as core, establish and improve the special evaluation mechanism of practical teaching, define the evaluation
The prevalence of undergraduate start-ups reflects the current employment situation and the reform of talent cultivation modes. Based on explaining the present situation of practical Bachelor training for start-ups, this paper brought up the establishment thoughts and the according measures, hoping to provide guidance for problems in the practical self employment in undergraduate education. We should continue to pay attention to and support college students' entrepreneurship projects, further promote and ensure that they receive more support in entrepreneurship, to solve some problems of employment and job supply \& demand. The discussion on the problems of entrepreneurship education of practiceoriented undergraduate college remains further tested and improved in the future teaching reforms.

\section{ACKNOWLEDGMENT}

Foundation Project: Research results of Humanities and Social Sciences Foundation Project (W2019lkyfwdf-04) which Serves Local Major Economic Development Project.

\section{REFERENCES}

[1] Song G.S, Liu F, Wang L.S., 2015, Discussion of Diversity of English Practice-Oriented System in Undergraduate Institutes, Knowledge Economy, pp. $125-125$

[2] Yao C.S., 2017, A Study on the Model of College English Teaching in Practice-Oriented Universities Based on Social Needs, Journal of Three Gorges University, pp. 192-193

[3] Zhu F.X., Shangguan J.Z., 2008, The Talent Cultivation Model of Practice-Oriented Undergraduate Colleges, Guide to Economic Research, pp. 234-235

[4] Yuan S.H., 2010, A Study on the Cultivation Mode of Practice-Oriented Undergraduate Talents, Vocational Technology, pp. 70-70

[5] Gao Z.L., 2010, An Analysis of Entrepreneurship Education of College Students, China Adult Education, pp. 66-67 
[6] Zhong W.B., 2015, Research on Entrepreneurship Education of Poor College Students, China Master's Theses Full-text Database

[7] Zhang J.B., Zhang Y.J., 2013, Research on the Construction of Entrepreneurship Education System in Practice-Oriented Undergraduate College and Universities, Journal of Jiangsu Teachers University of Technology, pp. 103-108 